\title{
De invloed van preferente beschermingsaandelen op aandelenkoersen
}

\author{
Drs. A.L.R. Cantrijn en Dr. M.R. Kabir
}

\section{Samenvatting ${ }^{1}$}

Dit werk is een empirisch onderzoek naar de invloed van beschermingsconstructies op dagelijkse aandelenkoersen. Omdat de bescherming met preferente aandelen de laatste jaren de meest gebruikte beschermingsmaatregel is in Nederland, is het koerseffect onderzocht van ondernemingen die in de periode 1984-1990 deze beschermingsmaatregel hebben ingevoerd. Eerst is het koerseffect onderzocht voor de totale steekproef van 44 beschermingsmaatregelen met preferente aandelen. Vervolgens is het beschermingsproces met preferente aandelen gesplitst in drie verschillende stappen (mogelijkheid scheppen, optieverlening en uitgifte), die afzonderlijk zijn geanalyseerd. Tenslotte is bekeken of er verschil is in een eerste of een extra bescherming met preferente aandelen. Het resultaat is een significant negatief koerseffect door de invoering van preferente beschermingsmaatregelen. Van de stappen in het beschermingsproces blijkt de uitgifte van preferente aandelen de bepalende stap te zijn die leidt tot dit negatieve koerseffect. Tevens blijkt dat een eerste uitgifte een sterker negatief effect heeft dan een extra uitgifte.

\section{Inleiding}

De laatste tijd worden de beschermingsmaatregelen ter discussie gesteld. De discussie spitst zich toe op de vraag tot welke grens ondernemingen zich mogen beschermen. In een discussie waarbij de partijen in plaats van in te gaan op elkaars argumenten zich grotendeels beperken tot het aandragen van andere argumenten, blijkt dat de meningen over dit on- derwerp sterk uiteen liggen (Frentrop, 1988). Deze discussie komt ook naar voren in het financiële nieuws waar een aantal personen hun meningen presenteren. ${ }^{2}$ Twee partijen, de Vereniging voor de Effectenhandel en de Vereniging van Effecten Uitgevende Ondernemingen, hebben te kennen gegeven nader te overleggen over de totstandkoming van een definitieve regeling inzake beschermingsconstructies vóór 1 januari 1992. Dat de meningen van deze partijen sterk uiteen liggen blijkt uit het feit dat de invoering van een nieuwe regeling was uitgesteld tot 1 april 1992. Onder druk van de minister van Financiën is er in mei toch een akkoord bereikt. Het Nederlandse recht biedt aan ondernemingen die zichzelf willen beschermen vele mogelijkheden. Ze kent weinig verbodsbepalingen ten aanzien van de wijze waarop, en de mate waarin, een onderneming zich beschermt. De Nederlandse praktijk wordt dan ook gekenmerkt door een sterke mate van bescherming. Van alle beursgenoteerde fondsen in 1988 is $81 \%$ door één of meerdere beschermingsconstructies sterk beschermd. De overige $19 \%$ onbeschermde fondsen is in handen van families. ${ }^{3} \mathrm{De}$ toepassing van beschermingsconstructies is in $\mathrm{Ne}$ derland sedert de jaren zestig een steeds belangrijkere rol gaan spelen ter afwering van overvallen en onvriendelijke overnames (Voogd, 1989). Het zijn met name dit soort overnemingen die in bepaalde andere landen, met name de Angelsaksische landen, veel gebruikelijker zijn dan in Nederland. In deze landen staat de positie van de aandeelhouder

Drs. A.L.R. Cantrijn studeerde bedrijfseconomie aan de Katholieke Universiteit Brabant, doctoraal in 1991.

Dr. M.R. Kabir MBA, MA (Econ.) is universitair docent ondernemingstinanciering aan de Katholieke Universiteit Brabant. 


\section{MAB}

voorop en niet, zoals in Nederland, de continuïteit van de onderneming. In de Angelsaksische landen is men van oordeel dat overnemingen tot op zekere hoogte de economie bevorderen, met name omdat besturen van beursgenoteerde ondernemingen er zich steeds van bewust zijn dat er een openbaar bod op hun vennootschap gedaan kan worden. Deze dreiging bevordert de inzet van besturen. Een overname zelf is een effectief instrument om een niet goed functionerend bestuur te vervangen (zie Moerland, 1989; Rietkerk, 1989; De Jong, 1990 en Voogd, 1990b voor een overzicht van de theoretische beschouwingen).

\section{De theoretische invloed van beschermingsconstructies op aandelenkoersen}

De theoretische invloed van beschermingsconstructies op aandelenkoersen is beschreven in twee aan elkaar tegengestelde hypotheses. Dit zijn de 'managerial entrenchment'-hypothese en de 'stockholder interests'-hypothese (DeAngelo en Rice, 1983; Dann en DeAngelo, 1983). De 'managerial entrenchment'-hypothese houdt in dat beschermingsconstructies er primair voor zorgen dat een slecht opererend management beter beschermd wordt en dat het recht van de beslissingsmacht van de huidige aandeelhouders wordt beperkt. Hierdoor zullen de 'monitoring'-kosten van de aandeelhouders oplopen. Tevens verhogen beschermingsconstructies de kosten van het afzetten van managers door de aandeelhouders. Uiteindelijk zal volgens de 'managerial entrenchment'-hypothese de totale marktwaarde van de geplaatste aandelen lager zijn door de invoering van beschermingsconstructies.

Een geheel andere verklaring voor de feitelijke volgzaamheid van aandeelhouders geeft de 'stockholder interests'-hypothese. Deze hypothese voorspelt dat de aanname van beschermingsconstructies de welvaart van de huidige aandeelhouders zal doen toenemen. Een argument hiervoor is dat door beschermingsconstructies het zittende bestuur zich op de lange termijn kan richten. Een ander argument is dat in de onderhandelingen met een gegadigde voor de onderneming het bestuur van een beschermde onderneming een sterke onderhandelingspositie kan innemen teneinde een zo hoog mogelijke prijs voor de aandelen te bedingen. Tenslotte zouden beschermingsconstructies kunnen voorkomen dat bestuurders meer kostbare vormen van verspilling van ondernemingsmiddelen ter hand nemen om een bestuursonvriendelijke overnamepoging te pareren. Dus zal volgens de 'stockholder interests'-visie de marktwaarde van de aandelen door invoering van beschermingsconstructies toenemen. In het empirisch onderzoek wat hierop volgt is getoetst welke hypothese voor de Nederlandse praktijk geldt. ${ }^{\star}$

\section{Preferente aandelen als bescherming}

Een aandelenemissie is primair bedoeld om risicodragend vermogen aan te trekken. Als preferente aandelen om deze reden worden uitgegeven dan spreekt men van preferente financieringsaandelen. De uitgifte van preferente aandelen in het kader van bescherming zorgt ervoor dat de zeggenschap van de bestaande aandeelhouders, waaronder de overvaller, verwatert. Uitgifte van preferente beschermingsaandelen biedt diverse voordelen boven uitgifte van gewone aandelen. Zo bestaat er bij de uitgifte van preferente aandelen geen voorkeursrecht voor houders van gewone aandelen en behoeven ze niet te worden volgestort. De minimale stortingsverplichting - bij bescherming zal men zich beperken tot dit minimum - bedraagt 25 procent. Een ander belangrijk voordeel van het gebruik van preferente aandelen is, dat als het overvalgevaar geweken is, de onderneming de aandelen kan intrekken. Als zodanig kan het gebruik van preferente beschermingsaandelen een tijdelijk karakter hebben (Schwarz, 1988). De preferente aandelen worden de laatste jaren in hoofdzaak geplaatst bij financiële instellingen/institutionele beleggers en vooral speciaal daarvoor opgerichte stichtingen.

In de praktijk verloopt de bescherming met preferente aandelen in een aantal stappen. Eerst moet de vergadering van aandeelhouders goedkeuring verlenen tot statutenwijziging om de preferente aandelen in de vermogensstructuur van de onderneming op te nemen. De volgende stap in het beschermingsproces kan een optieverlening zijn. De emissiebevoegdheid, die in beginsel toekomt aan de algemene vergadering van aandeelhouders, kan voor de duur van vijf jaar aan een ander orgaan worden 
gedelegeerd. Indien het bestuur emissiebevoegd is, kan zich het geval voordoen dat de termijn waarvoor de delegatie geldt afloopt, terwijl de directie moeilijkheden voorziet waar het een nieuwe delegatie betreft. Gesteld wordt dat onder deze omstandigheden een optie aan de bevriende instantie - veelal een stichting - verleend kan worden zodat de aandelen uitgegeven kunnen worden wanneer de directie niet meer bevoegd is. De uitgifte berust op het optiebesluit dat genomen werd toen het bestuur nog emissiebevoegd was (Blanco Fernandez, 1989). Met de bovenstaande geschapen mogelijkheden kunnen als derde stap preferente beschermingsaandelen worden uitgegeven als er sprake is van een overnamedreiging. Als het gevaar tenslotte geweken is kan de onderneming de aandelen weer intrekken. Hieruit blijkt het tijdelijke karakter van preferente aandelen. Deze verschillende stappen vinden veelal niet gelijktijdig plaats. Zo kan het voorkomen dat een onderneming op een bepaald tijdstip de mogelijkheid schept tot uitgifte van preferente aandelen, terwijl jaren later bij een overnamedreiging de preferente aandelen worden uitgegeven.

\section{Data}

Om de in de afgelopen jaren in Nederland ingevoerde beschermingsmaatregelen met preferente aandelen te lokaliseren zijn de volgende bronnen geraadpleegd: de index van het blad Beursplein 5 (periode 1986-1990), bijlage 2 van Voogd (1989) (periode 1984-1985), bijlagen 1 van Voogd (1989, 1990a) (periode 1 januari 1988 tot 10 november 1989) en Het Financieele Dagblad (1984-1990). Blijkens deze waarnemingen zijn er 51 beschermingsmaatregelen met preferente aandelen getroffen in de periode $1984-1990{ }^{6}$ Drie beschermingsmaatregelen die zijn afgekeurd door de aandeelhoudersvergadering zijn niet in het onderzoek opgenomen omdat er dan alleen gesproken kan worden van een voornemen en niet van een reële maatregel. De 51 beschermingsmaatregelen die zijn getroffen met preferente aandelen hebben betrekking op 40 verschillende beursgenoteerde ondernemingen.

Deze beschermingsmaatregelen zijn nader geanalyseerd met behulp van Het Financieele Dagblad en het blad Beursplein 5. Er is gezocht naar berichten die betrekking hadden op de beschermingsmaatregelen van de desbetreffende ondernemingen. Van twee ondernemingen, die zijn verkregen uit de bijlagen 1 van Voogd (1989, 1990a), zijn bij nader onderzoek in Het Financieele Dagblad en Beursplein 5 geen berichten gevonden omtrent de voorgenomen beschermingsmaatregelen met preferente aandelen. Omdat er dus geen duidelijke bekendmakingsdatum voor deze ondernemingen is te vinden, zijn ze niet in de steekproef opgenomen. Twee andere ondernemingen zijn ook niet in de steekproef opgenomen, omdat er naast de bekendmaking van de bescherming ook andere sterk langdurig koersgevoelige informatie vrijkwam. ${ }^{7}$ Totaal zijn er in de steekproef 47 beschermingsmaatregelen met preferente aandelen opgenomen voor verdere analyse. Deze zijn gepresenteerd in tabel 1.

De steekproef is op basis van de beschreven drie stappen als volgt in te delen:

- 17 maatregelen waardoor de statutaire mogelijkheid is geschapen tot uitgifte van preferente beschermingsaandelen; het betreft hier allemaal verschillende ondernemingen;

- 12 optieverleningen aan de stichting (of bevriende relatie) tot het nemen van preferente aandelen; het betreft hier allemaal verschillende ondernemingen;

- 18 uitgiften van preferente beschermingsaandelen aan de stichting (of bevriende relatie); 2 ondernemingen hebben in deze periode twee maal preferente aandelen geplaatst.

Deze indeling is eveneens in tabel 1 vermeld. Zevenentwintig ondernemingen uit deze steekproef hebben één stap in het beschermingsproces genomen, terwijl 9 ondernemingen twee stappen hebben genomen. Geen enkele onderneming heeft in deze periode alle drie stappen genomen.

Tevens is het mogelijk om de bestaande maatregelen met preferente beschermingsaandelen uit te breiden. Als er sprake van is dat een bepaalde beschermingsmaatregel niet voor het eerst wordt genomen, dan wordt hier gesproken over een 'extra' maatregel en is deze als zodanig gekenmerkt. Van de 47 maatregelen zijn er 11 'extra' maatregelen. Drie van de 17 maatregelen waarvoor de statutaire mogelijkheid is geschapen, zijn maatregelen die 
Tabel 1: Nederlandse beursgenoteerde ondernemingen die zich hebben beschermd met preferente aandelen in de periode 1984-1990

onderneming

Ahold

Ahold

AMEV

AMEV

Assurantieconcern Stad Rotterdam

Braat Beheer

Cindu-Key \& Kramer

Desseaux

Desseaux

Eriks Holding

Eriks Holding

Geveke Electronics International

Gist-Brocades

Grasso's Koninklijke Machinefabrieken

Grolsch Bierbrouwerij

Grolsch Bierbrouwerij

H.E.S. Beheer

HCS Technology

Holdoh-Houtunie

Hollandsche Beton Groep

Ingenieurs Bureau Bouwnijverheid - Kondor Groep

Investeringsmaatschappij Nederland Holding

KLM

Koppelpoort Holding

Koppelpoort Holding

Melia international

Multihouse

Multihouse

NBM-Amstelland

Pakhoed Holding

Philips

Polynorm

Reesink

Reesink

Samas-groep

Sanders Behang

Sphinx

Ubbink

Verenigde Machinefabrieken Stork

Verenigde Machinefabrieken Stork

Verenigde Instrumentenfabrieken Enraf-Nonius

Verkade

Verto

Volker Stevin

Volker Stevin

Volker Stevin

Wolff Handelsmaatschappij bekend-

makings-

datum stap in het

beschermingsproces
27 feb ' 89

28 aug ' 89

29 aug ' 85

29 dec ' 88

13 mei ' 85

2 jun ' 89

19 sep ' 89

27 nov ' 84

13 jun ' 85

24 feb ' 89

20 okt ' 89

14 mrt ' 86

2 aug ' 89

19 apr ' 89

13 sep ' 89

9 nov' '89

5 jun '89

19 jul ' 88

6 nov '86

24 mei '85

10 mei '89

23 dec ' 88

6 feb ' 86

22 aug ' 84

10 jun ' 85

4 sep ' 87

24 feb ' 88

24 feb ' 89

18 mei '89

4 apr ' 89

$7 \mathrm{mrt}$ ' 89

3 mei ' 89

14 sep '88

$15 \mathrm{mrt}$ ' 89

1 jul ' 88

12 mrt ' 87

8 jun '89

28 apr ' 88

6 mei '86

2 mei '89

4 aug '89

17 okt ' 88

6 apr ' 88

3 okt ' 88

20 dec '88

30 jan ' 89

18 apr ' 88 optieverlening

extra uitgifte

extra uitgifte

extra optieverlening

uitgifte

mogelijkheid scheppen

uitgifte

mogelijkheid scheppen

uitgifte

mogelijkheid scheppen

optieverlening

mogelijkheid scheppen

optieverlening

optieverlening

mogelijkheid scheppen

optieverlening

mogelijkheid scheppen

uitgifte

uitgifte

extra uitgifte

optieverlening

mogelijkheid scheppen

optieverlening

mogelijkheid scheppen

uitgifte

uitgifte

uitgifte

extra uitgifte

extra mogelijkheid scheppen

mogelijkheid scheppen

mogelijkheid scheppen

mogelijkheid scheppen

extra mogelijkheid scheppen

extra optieverlening

optieverlening

uitgifte

mogelijkheid scheppen

mogelijkheid scheppen

optieverlening

extra mogelijkheid scheppen

mogelijkheid scheppen

uitgifte

uitgifte

uitgifte

extra uitgifte

extra optieverlening

uitgifte

Bron: Het Financieele Dagblad en het blad Beursplein 5 
de mogelijkheid tot uitgifte van preferente aandelen hebben verhoogd in de periode 1984-1990. Van de 12 optieverleningen zijn er eveneens 3 waardoor de bestaande optie aan de stichting werd vergroot. Vijf van de 18 uitgiften betreffen een toevoeging aan het bestaande preferente aandelenvermogen.

Uitgaande van een efficiënte aandelenmarkt, waar nieuw ter beschikking komende informatie onmiddellijk en volledig in de beurskoers wordt opgenomen, is het noodzakelijk voor het onderzoek te weten op welk tijdstip de beschermingsmaatregel voor het eerst publiek bekend werd. Wat betreft de statutaire mogelijkheid tot uitgifte van preferente aandelen is de dag van de aandeelhoudersvergadering als relevant tijdstip te laat, omdat de aandeelhouders al eerder in kennis zijn gesteld van de voorgenomen beschermingsmaatregel. De aandeelhouders moeten wettelijk vooraf worden ingelicht over de agendapunten van de aandeelhoudersvergadering. Een onderneming dient daarom ruim voor de aandeelhoudersvergadering de agenda te publiceren in een landelijk dagblad. Als in deze publikatie voor het eerst het voornemen van de beschermingsmaatregel publiek kenbaar wordt gemaakt, is deze datum als bekendmakingsdatum aangemerkt. Het voornemen om de onderneming te beschermen wordt veelal ook eerder kenbaar gemaakt. Zo kunnen ondernemingen hun voornemen tot bescherming kenbaar maken bij de presentatie van het jaarverslag of worden aandeelhouders bij een eerdere aandeelhoudersvergadering over het voornemen ingelicht. Andere ondernemingen berichten over het voornemen door middel van een persconferentie of persbericht. Zijn de te nemen maatregelen eerder bekend, dan is deze datum aangemerkt als de eerste bekendmakingsdatum.

Voor de gevallen van optieverlening en uitgifte is de toestemming van de aandeelhouders niet meer nodig. Het bestuur van de onderneming kan zelf beslissen wanneer het zo'n maatregel ten uitvoer brengt. Als bekendmakingsdatum is daarom de datum aangemerkt wanneer de onderneming de maatregel publiek kenbaar heeft gemaakt. Een onderneming kan deze maatregelen vooraf kenbaar maken. Maar zij kan ook de maatregel achteraf kenbaar maken. Is de maatregel achteraf kenbaar gemaakt, dan is de datum wanneer de maatregel is uitgevoerd als bekendmakingsdatum genomen.

De meeste data zijn verkregen uit Het Financieele Dagblad en enkele uit het blad Beursplein 5. Omdat het nieuws al één werkdag vóór de verschijningsdatum van Het Financieele Dagblad bekend wordt gemaakt ${ }^{8}$, is de werkdag vóór de verschijning van Het Financieele Dagblad als bekendmakingsdatum aangemerkt. Als de dag van uitvoering van de beschermingsmaatregel de bekendmakingsdatum is, dan is deze datum gebruikt. Tenslotte zijn de dagelijkse koersgegevens verzameld via Datastream, waarbij rekening is gehouden met uitkering van contante dividenden en mutaties in de vermogensstructuur (bijvoorbeeld aandelensplitsing, stockdividend en claim-emissies).

\section{Methodologie}

Om de invloed van preferente beschermingsaandelen op aandelenkoersen te onderzoeken is gebruik gemaakt van de 'event study'-methodiek ${ }^{9}$ van Brown en Warner (1980, 1985). Er wordt uitgegaan van het standaard één factor Markt Model. Het Markt Model veronderstelt dat aandelenkoersen van individuele ondernemingen in de tijd in een bepaalde relatie staan tot die van alle aandelen op de markt. Het rendement van een individueel aandeel is volgens dit model lineair gerelateerd aan het rendement van de markt. In formulevorm:

$R_{j t}=\alpha_{j}+\beta_{j} R_{m t}+e_{j t}$

Hierin is:

$\mathrm{R}_{\mathrm{jt}}=$ het rendement van aandeel $\mathrm{j}$ in periode $\mathrm{t}$, gedefinieerd als het continue rendement van het aandeel, bepaald als $\ln \left(\left(P_{t}+D_{t}\right) /\right.$ $P_{t^{-1}}$ ) waar $P_{t}$ de aandeelprijs aan het einde van de periode is, $P_{t-1}$ de aandeelprijs aan het einde van de vorige periode en $D_{t}$ de contante dividenduitkering tijdens de periode,

$R_{m t}=$ het rendement van de markt in periode $t$, gedefinieerd als het continue rendement van de CBS-herbeleggingsindex, bepaald als $\ln \left(\right.$ index $_{t} /$ index $_{t-1}$ ),

$\alpha_{j}, \beta_{j}=$ de tijdsonafhankelijke parameters van de relatie tussen het rendement van het specifiek aandeel $j$ en het rendement van de markt, 


\section{MAB}

$\mathrm{e}_{\mathrm{jt}}=$ de storingsterm van aandeel $\mathrm{j}$ in periode $\mathrm{t}$, met de verwachte waarde 0 en met een constante variantie.

Met de veronderstellingen ten aanzien van $e_{j t}$ en het vorenstaande model kunnen we aannemen dat het verwachte rendement van aandeel $j$ wordt weergegeven door:

$E\left(R_{j t}\right)=\hat{\alpha}_{j}+\hat{\beta}_{j} E\left(R_{m t}\right)$.

De parameters $\alpha_{j}$ en $\beta_{j}$ zijn hierbij geschat door een regressieanalyse met de kleinste kwadraten methode en leveren de schattingen $\hat{\alpha}_{\mathrm{j}}$ en $\hat{\beta}_{\mathrm{j}}$. Bij deze schatting is gebruik gemaakt van rendementen van de specifieke ondernemingen en de markt in een periode die valt buiten de 'event'-periode, de periode rond de bekendmaking. Het schattingsinterval van deze regressieparameters, de schattingsperiode, is gekozen als de periode van 100 dagen vóór aanvang van de 'event'-periode. Als 'event'-periode is hier gekozen voor de periode van 20 dagen vóor de bekendmaking tot 20 dagen na de bekendmaking van de beschermingsmaatregel.

Vervolgens is met deze voor elke onderneming specifieke relaties het buitengewoon rendement bepaald voor de 'event'-periode waar de nieuwe informatie bekend werd. Het buitengewoon rendement wordt verondersteld het effect weer te geven van de invoering van de beschermingsconstructie op de aandelenkoers. De bepaling van het buitengewoon rendement $(A R)$ in de 'event'-periode wordt als volgt weergegeven:

$A R_{j t}=R_{j t}-\left(\hat{\alpha}_{j}+\hat{\beta}_{j} R_{m t}\right)=\hat{e}_{j t}$.

Hierin behoort $t$ tot de 'event'-periode. Om te zien of de hieruit volgende resultaten op basis van het Markt Model worden beïnvloed door de specificaties van dit model is het vergeleken met het 'Market Adjusted Returns' model. De bepaling van het buitengewoon rendement (AR) van de specifieke onderneming j wordt dan als volgt weergegeven:

$A R_{j t}=R_{j t}-R_{m t}$.

Om te voorkomen dat de buitengewone rendementen worden beïnvloed door schattingsfouten en andere niet gerelateerde effecten op de specifieke aandelen, wordt de invloed van de invoering van beschermingsconstructies op koersrendementen in de 'event'-periode bepaald door het gemiddelde buitengewoon rendement (AAR) van alle in de steekproef opgenomen waarnemingen te berekenen. Dit gemiddelde buitengewone rendement wordt als volgt bepaald:

$$
A A R_{1}=(1 / N) \sum_{j=1}^{k} A R_{j t} .
$$

Hierin is $\mathrm{N}$ het aantal in de steekproef opgenomen aandelen van de verschillende ondernemingen op de datum $t$ in de 'event'-periode. Tevens is voor het onderzoek het gecumuleerde gemiddelde buitengewoon rendement (CAAR) van dag $k$ tot en met dag I bepaald. Dit wordt als volgt weergegeven:

$$
\mathrm{CAAR}=\sum_{\mathrm{t}=\mathrm{k}}^{1} \mathrm{AAR}_{\mathrm{t}}
$$

Om te weten of het buitengewoon rendement significant van 0 verschillend is, zal eerst een geschikte t-toets moeten worden uitgevoerd. Er wordt verondersteld dat de buitengewone rendementen onafhankelijk, stationair en bij benadering normaal verdeeld zijn. De t-toets voor $A_{A} R_{t}$ wordt als volgt:

$$
t(A A R)=A A R_{t} / \hat{\sigma}
$$

Hierin is $\hat{\sigma}$ de schatting van de standaard-deviatie van het dagelijkse gemiddelde buitengewoon rendement in de schattingsperiode. Ook is te bepalen of het gecumuleerde gemiddelde buitengewoon rendement significant van 0 verschillend is. De t-toets voor $\mathrm{CAAR}_{t}$ is als volgt:

$t(C A A R)=\mathrm{CAAR}_{\mathrm{t}} / \hat{\sigma} \sqrt{ } d$

Hierin is $d$ het aantal verhandeldagen in de 'event'periode, gedefinieerd als $(k-1+1)$. 


\section{Resultaten}

\subsection{De totale steekproef}

De totale steekproef betreft hier 44 beschermingsmaatregelen met preferente aandelen in de periode 1984-1990. Drie ${ }^{10}$ van de 47 beschermingsmaatregelen zijn niet in het vervolg van het onderzoek opgenomen, omdat de schattingsperiode samenviel met de 'event'-periode van een eerdere beschermingsmaatregel met preferente aandelen van de betreffende onderneming. Voor een drietal bescher- mingsmaatregelen"1 is de schattingsperiode van 100 dagen aan het begin met enkele dagen verkort, omdat deze dagen samenvielen met een vorige be scherming met preferente aandelen van de onderneming.

Tabel 2 geeft de resultaten van alle beschermingsmaatregelen met preferente aandelen in de 'event'periode op basis van het Markt Model. De tabel bevat de buitengewone rendementen (AAR) alsmede de gecumuleerde buitengewone rendementen (CAAR) voor de dagen in de 'event'-periode. In de

Tabel 2: De dagelijkse gemiddelde buitengewone rendementen van de totale steekproef op basis van het Markt Model

\begin{tabular}{|c|c|c|c|c|c|}
\hline $\begin{array}{r}\text { dagen ten } \\
\text { opzichte van } \\
\text { bekendmakings- } \\
\text { datum }\end{array}$ & AAR (in \%) & $t(A A R)$ & CAAR (in \%) & $t(C A A R)$ & $\begin{array}{r}\% \text { negatief } \\
\text { van een } \\
\text { bepaalde dag }\end{array}$ \\
\hline-20 & 0.336 & 1.078 & 0.336 & 1.078 & 48 \\
\hline-15 & 0.098 & 0.314 & 0.556 & 0.728 & 57 \\
\hline-10 & -0.440 & -1.411 & -0.120 & -0.116 & 61 \\
\hline-5 & -0.232 & -0.744 & 0.119 & 0.095 & 59 \\
\hline-4 & 0.404 & 1.296 & 0.523 & 0.407 & 50 \\
\hline-3 & 0.047 & 0.151 & 0.570 & 0.431 & 50 \\
\hline-2 & 0.454 & 1.456 & 1.024 & 0.753 & 57 \\
\hline-1 & 0.035 & 0.112 & 1.059 & 0.760 & 61 \\
\hline 0 & -0.680 & $-2.181^{\star}$ & 0.379 & 0.265 & 61 \\
\hline 1 & -0.496 & -1.591 & -0.117 & -0.080 & 64 \\
\hline 2 & -0.229 & -0.734 & -0.346 & -0.231 & 61 \\
\hline 3 & -0.599 & -1.921 & -0.945 & -0.619 & 73 \\
\hline 4 & -0.465 & -1.491 & -1.410 & -0.904 & 71 \\
\hline 5 & 0.199 & 0.638 & -1.211 & -0.762 & 48 \\
\hline 10 & -0.151 & -0.484 & -1.330 & -0.766 & 55 \\
\hline 15 & -0.135 & -0.433 & -1.470 & -0.786 & 59 \\
\hline 20 & -0.497 & -1.594 & -2.503 & -1.254 & 61 \\
\hline
\end{tabular}

\begin{tabular}{ccc}
\hline dagen ten opzichte van bekendmakingsdatum & CAAR (in \%) & t(CAAR) \\
\hline$-20 t / m-1$ & 1.059 & 0.760 \\
$0 t / m+1$ & -1.176 & $-2.667^{\star}$ \\
$0 t / m+5$ & -2.270 & $-2.972^{*}$ \\
$0 t / m+20$ & -3.562 & $-2.493^{*}$ \\
\hline
\end{tabular}

\footnotetext{
" toont aan dat het buitengewoon rendement significant van 0 verschillend is met een significantie-niveau van $5 \%$.
} 


\section{MAB}

bekendmakingsperiode $[0,+1]$ van de beschermingsmaatregel lijden de aandeelhouders een significant buitengewoon rendementsverlies van $1.18 \%$ $(\mathrm{t}=-2.67)$. De periode vanaf de bekendmaking van de bescherming tot het einde van de 'event'-periode $[0,+20]$ levert een significant koerseffect van $-3.56 \%$ $(\mathrm{t}=-2.49)$ op.

Als wordt gekeken naar het percentage negatieve dagelijkse buitengewone rendementen (kolom 6) van de betreffende beschermingsmaatregelen in de 'event'-periode dan kan geconcludeerd worden dat voor de meeste dagen meer dan de helft van de beschermingsmaatregelen negatief is. Enkele forse negatieve uitschieters kunnen daarom niet het resultaat bepalen. Hieruit kan worden afgeleid dat het negatieve koerseffect niet wordt bepaald door beschermingsmaatregelen van enkele ondernemingen, maar door maatregelen van het merendeel der ondernemingen.

Om deze resultaten te verduidelijken zijn ze grafisch weergegeven in de grafieken 1 en 2 . Grafiek 1 vertoont de gemiddelde buitengewone rendementen in de 'event'-periode. Het meest opvallende element dat uit deze grafiek naar voren komt, is de daling van de aandelenkoers in de bekendmakingsperiode $[0,+1]$. Grafiek 2 geeft een voorstelling van de ge- middelde gecumuleerde buitengewone rendementen in de 'event'-periode. Het meest in het oog springende resultaat is de al eerder gesignaleerde koersdaling na de bekendmaking. Tevens is te zien dat de koers een hoogtepunt bereikt net voor de bekendmaking.

De analyse is ook uitgevoerd op basis van het 'Market Adjusted Returns' model. Omdat er geen essentiële verschillen zijn tussen de resultaten van beide modellen, zijn deze resultaten niet gepresenteerd.

\subsection{De uitgifte van preferente beschermingsaande-} len

Als alle 44 beschermingsmaatregelen worden onderverdeeld in één van de drie stappen van het beschermingsproces dan blijkt dat stap 1, de mogelijkheid scheppen tot uitgifte en stap 2, de optieverlening tot het nemen van preferente aandelen geen significante effecten opleveren (zie tabel 3). ${ }^{12}$ Uit de analyse van de resultaten blijkt dat het significante effect van de totale steekproef wordt bepaald door de uitgifte van de preferente beschermingsaandelen. In tabel 3 (panel C) zijn ook de resultaten weergegeven voor de 17 uitgiften van preferente beschermingsaandelen ${ }^{13}$ in de 'event'-periode.

De bekend making levert een significant koerseffect van $-4.09 \%(t=-4.94)$. Ook de dagen na de

Grafiek 1: De dagelijkse gemiddelde buitengewone rendementen van de totale steekproef op basis van het Markt Model

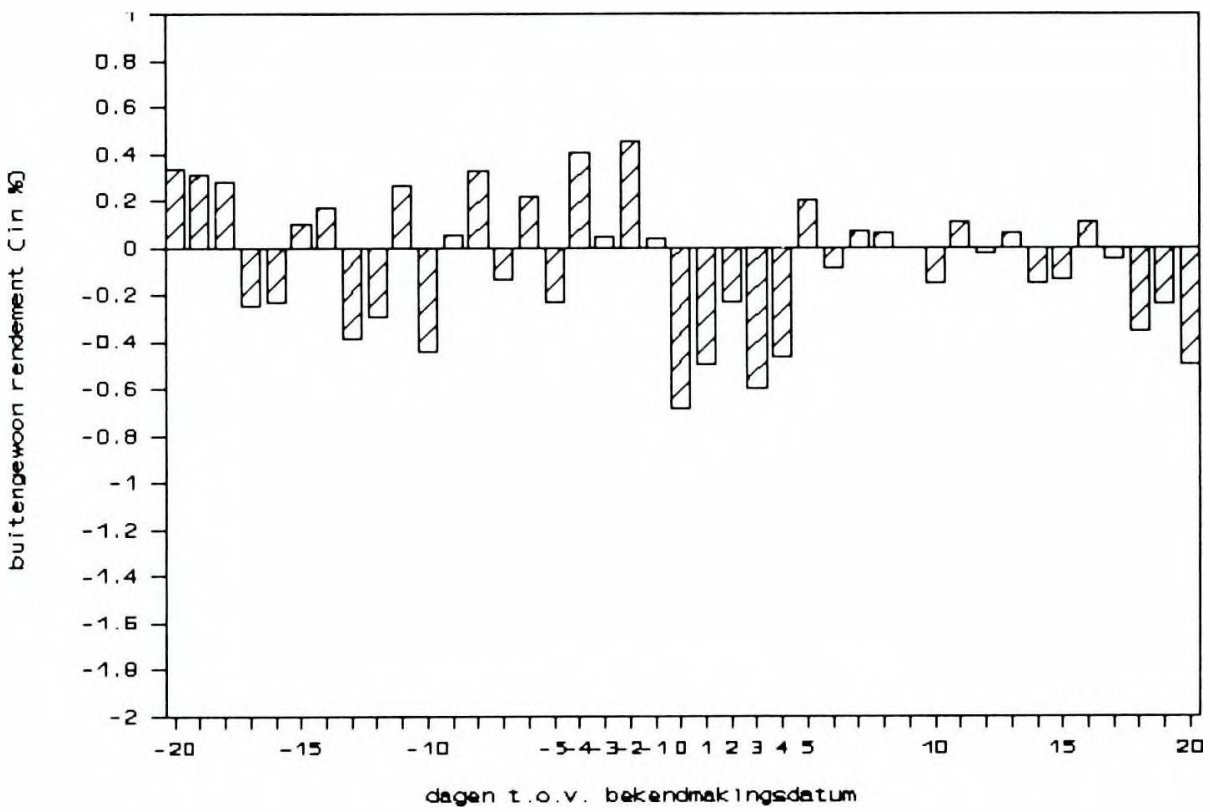


Grafiek 2: De dagelijkse gecumuleerde gemiddelde buitengewone rendementen van de totale steekproef op basis van het Markt Model

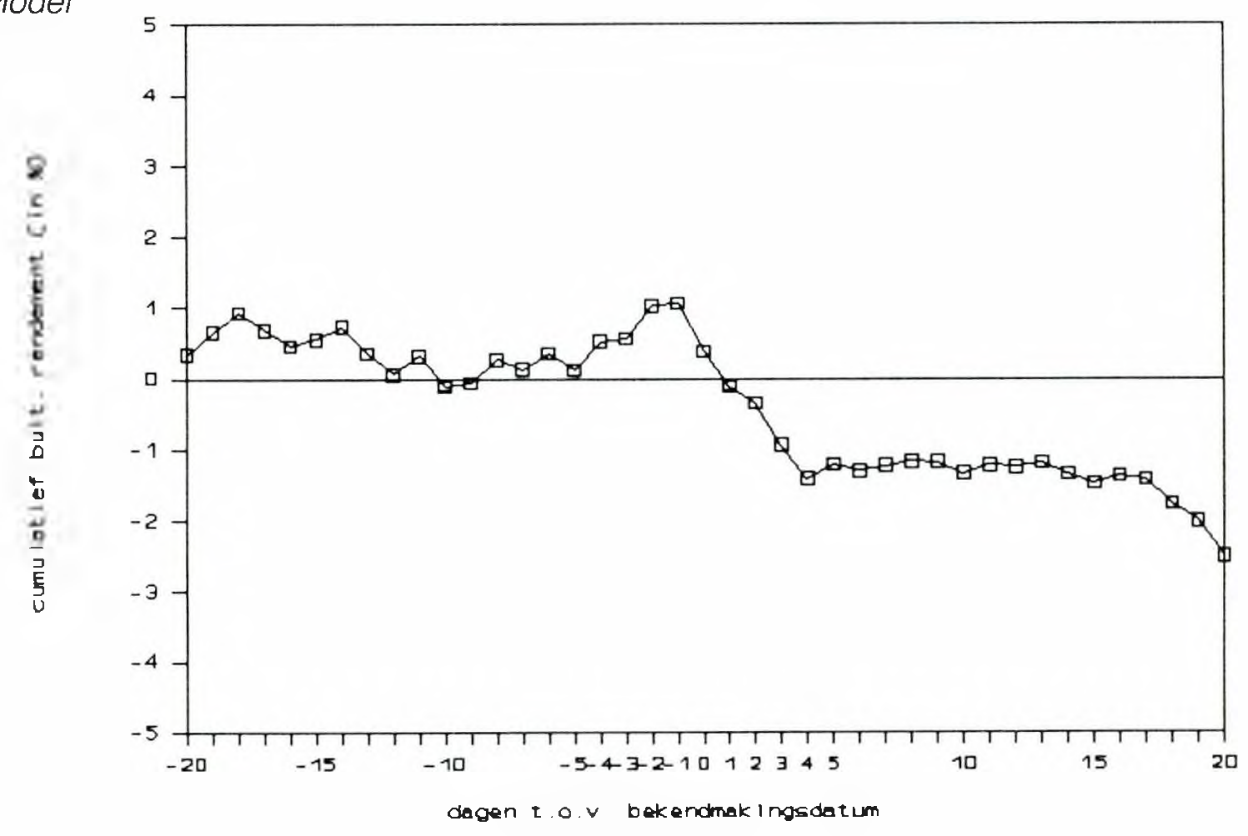

bekendmaking zijn er overwegend negatieve buitengewone rendementen. Voor de periode $[0,+5]$ is het rendementsverlies opgelopen tot $6.40 \%$. Dit effect wordt nog eens benadrukt door het feit dat ruim $75 \%$ van de uitgiften een negatief koerseffect vertoont op de dag van bekendmaking. Hieruit kan worden afgeleid dat er een sterk negatief koerseffect uitgaat van de bekendmaking van uitgifte van preferente beschermingsaandelen.

Als de periode voor de bekendmaking in ogenschouw wordt genomen dan wordt deze periode gekenmerkt door een koersstijging. De periode voorafgaand aan de bekendmaking $[-20,-1]$ levert dan ook een koerseffect van $4.93 \%$. De sterke koersstijgingen kunnen een indicator zijn voor een mogelijke overval. Dit kan voor besturen van deze ondernemingen een aanleiding tot bescherming zijn. Als de periode vanaf de bekendmaking $[0,+20]$ wordt geanalyseerd, dan is het rendementsverlies zelfs $9.64 \%$. Dit is gerelateerd aan het jaarlijkse rendement van de aandeelhouders een opmerkelijk verlies.

Grafisch zijn deze resultaten voorgesteld in de grafieken 3 en 4 (zie p. 337). De grafieken geven het verloop van de gemiddelde buitengewone rendementen en het gemiddelde gecumuleerde buiten- gewone rendement. Deze grafieken vertonen grote overeenkomsten met de grafieken 1 en 2. Maar het effect in deze steekproef is sterker dan het effect van de totale steekproef. Hieruit valt af te leiden dat het effect van de totale steekproef sterk wordt bepaald door de uitgifte van preferente beschermingsaandelen. Uit grafiek 4 blijkt dat de aandelenkoers zijn hoogtepunt bereikt op de dag voor de bekendmaking. Vervolgens treedt er naar aanleiding van de bekendmaking van de uitgifte een sterke daling op, die wordt geremd vier dagen na de bekendmaking. Uiteindelijk daalt dit gecumuleerde rendement naar een niveau van $-9.64 \%$ aan het einde van de 'event'-periode. Door deze resultaten is met grote zekerheid te zeggen dat van de uitgifte van preferente beschermingsaandelen een sterk drukkende werking uitgaat op de aandelenkoersen van de betreffende ondernemingen.

6.3 Extra uitgifte van preferente beschermingsaandelen

Uit de vorige paragraaf is gebleken dat de uitgifte van preferente beschermingsaandelen de beslissende stap is waar het significante negatieve effect van de totale steekproef door wordt bepaald. Omdat er in de steekproef van uitgiften een verband bestaat tussen de aandelenkoers en de bescherming is 


\section{MAB}

Grafiek 3: De dagelijkse gemiddelde buitengewone rendementen van de uitgifte van preferente beschermingsaandelen op basis van het Markt Model

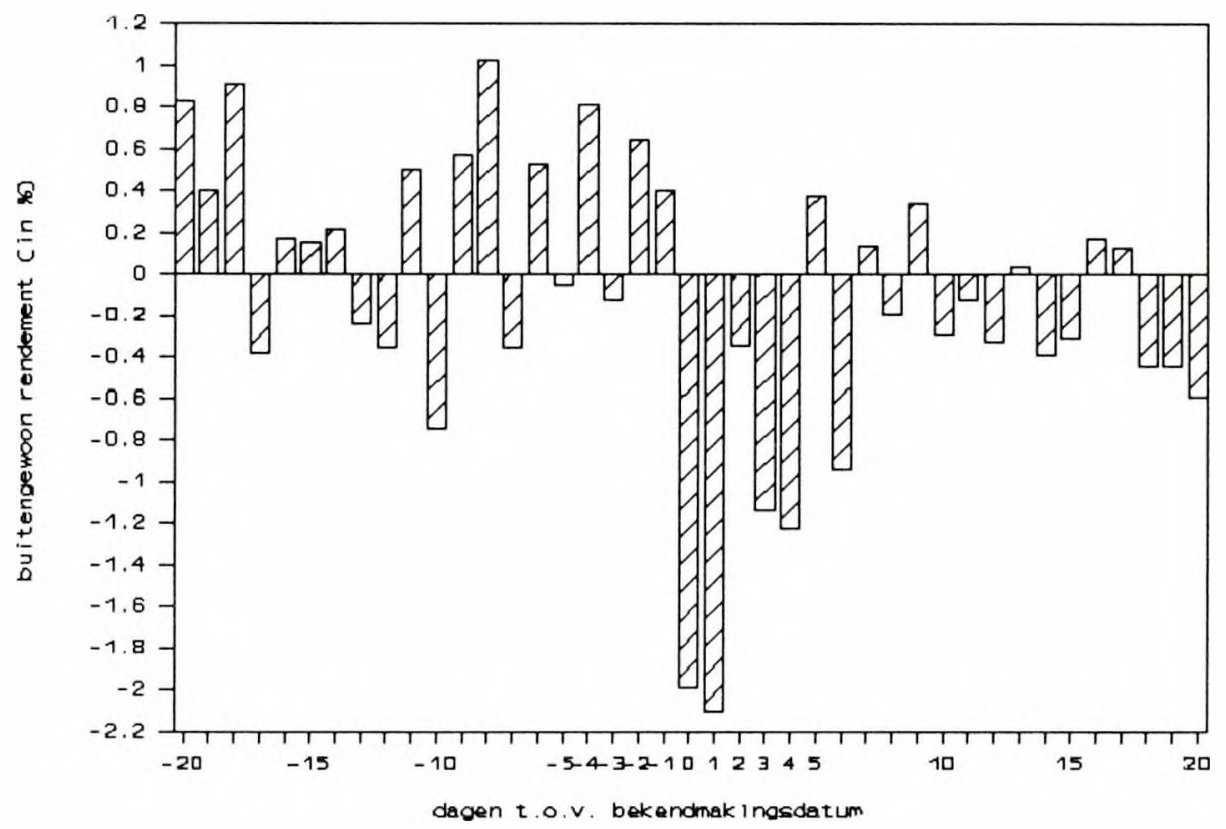

het dus interessant om te kijken of er een verschil is in dit verband tussen een eerste uitgifte en een extra uitgifte van preferente aandelen. Daarom wordt de steekproef van 17 uitgiften verdeeld in een steekproef van 13 ondernemingen die voor het eerst preferente beschermingsaandelen hebben uitgegeven en een steekproef van 4 ondernemingen die zich extra hebben beschermd. ${ }^{14}$ De resultaten op basis van het Markt Model zijn weergegeven in tabel 3 (Panel D en E). Als wordt gekeken naar het effect van de bekendmaking dan treft een extra uitgifte de aandeelhouders minder zwaar dan de eerste uitgifte. In de periode $[0,+5]$ is dit verschil in rendementsverlies nog groter geworden, het rendeGrafiek 4: De dagelijkse gecumuleerde gemiddelde buitengewone rendementen van de uitgifte van preferente beschermingsaandelen op basis van het Markt Model

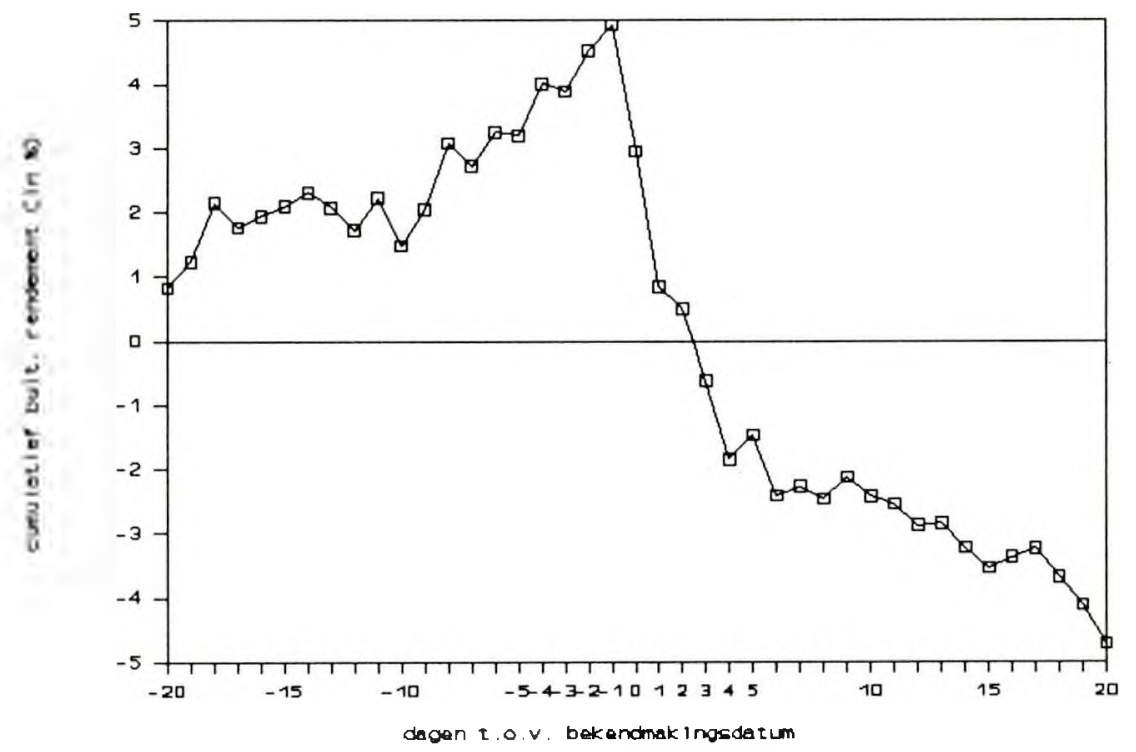


Tabel 3: De gecumuleerde gemiddelde buitengewone rendementen rond de bekendmaking van de beschermingsmaatregel op basis van het Markt Model

A Stap 1: mogelijkheid scheppen tot uitgifte $(\boldsymbol{N}=\mathbf{1 7})$
\begin{tabular}{lcr}
\hline $\begin{array}{l}\text { dagen ten opzichte van } \\
\text { bekendmakingsdatum }\end{array}$ & CAAR (in \%) & t(CAAR) \\
\hline$-20 t / m-1$ & -3.108 & -1.416 \\
$0 \mathrm{t} / \mathrm{m}+1$ & 1.230 & 1.772 \\
$0 \mathrm{t} / \mathrm{m}+5$ & 0.006 & 0.005 \\
$0 \mathrm{t} / \mathrm{m}+20$ & 1.434 & 0.638 \\
\hline
\end{tabular}

B Stap 2: optieverlening aan de stichting/bevriende relatie $(N=10)$

\begin{tabular}{ccr}
$\begin{array}{l}\text { dagen ten opzichte van } \\
\text { bekendmakingsdatum }\end{array}$ & CAAR (in \%) & t(CAAR) \\
\hline$-20 \mathrm{t} / \mathrm{m}-1$ & 0.498 & 0.218 \\
$0 \mathrm{t} / \mathrm{m}+1$ & -0.409 & -0.567 \\
$0 \mathrm{t} / \mathrm{m}+5$ & -0.417 & -0.333 \\
$0 \mathrm{t} / \mathrm{m}+20$ & -2.814 & -1.202 \\
\hline
\end{tabular}

C Stap 3: uitgifte van preferente aandelen $(N=17)$

\begin{tabular}{ccc}
\hline $\begin{array}{l}\text { dagen ten opzichte van } \\
\text { bekendmakingsdatum }\end{array}$ & CAAR (in \%) & t(CAAR) \\
\hline$-20 \mathrm{t} / \mathrm{m}-1$ & 4.933 & 1.884 \\
$0 \mathrm{t} / \mathrm{m}+1$ & -4.091 & $-4.940^{*}$ \\
$0 \mathrm{t} / \mathrm{m}+5$ & -6.404 & -4.465 * \\
$0 \mathrm{t} / \mathrm{m}+20$ & -9.645 & -3.594 \\
\hline
\end{tabular}

$D$ Eerste uitgifte van preferente aandelen ( $N=13)$

\begin{tabular}{crr}
\hline $\begin{array}{l}\text { dagen ten opzichte van } \\
\text { bekendmakingsdatum }\end{array}$ & CAAR (in \%) & t(CAAR) \\
\hline$-20 t / m-1$ & 4.365 & 1.320 \\
$0 t / m+1$ & -4.184 & $-4.000^{*}$ \\
$0 t / m+5$ & -7.030 & $-3.880^{*}$ \\
$0 \mathrm{t} / \mathrm{m}+20$ & -11.735 & $-3.462^{*}$
\end{tabular}

E Extra uitgifte van preferente aandelen $(N=4)$

\begin{tabular}{ccr}
$\begin{array}{l}\text { dagen ten opzichte van } \\
\text { bekendmakingsdatum }\end{array}$ & CAAR (in \%) & t(CAAR) \\
\hline$-20 t / m-1$ & 6.778 & 2.297 * \\
$0 t / m+1$ & -3.788 & -4.060 * \\
$0 t / m+5$ & -4.373 & -2.706 \\
$0 t / m+20$ & -2.849 & -0.943 \\
\hline
\end{tabular}

* toont aan dat het buitengewoon rendement significant van 0 verschillend is met een significantie-niveau van $5 \%$. mentsverlies van een eerste uitgifte is $2.66 \%$ groter dan van een extra uitgifte. Voor de periode $[0,+20]$ is dit verschil zelfs $8.89 \%$.

Het verloop van de extra plaatsing verschilt op een aantal punten ten opzichte van de eerste plaatsing. Ten eerste wordt de periode voor de bekendmaking gekenmerkt door een zeer sterke koersstijging. Deze nog sterkere stijging van de koers kan waarschijnlijk de aanleiding zijn van de betreffende onderneming om zich extra te beschermen. Een ander kenmerkend verschil tussen beide is de periode na de bekendmaking. De extra bescherming treft de onderneming minder dan de eerste bescherming. Voor de eerste bescherming blijkt er nagenoeg een continue daling van de aandelenkoers te zijn vanaf het moment van de bekendmaking. De koersdaling van de extra bescherming blijkt voornamelijk geconcentreerd te zijn in de periode van bekendmaking. Uit deze resultaten kan worden afgeleid dat de extra plaatsing een minder groot negatief koerseffect heeft dan de eerste plaatsing.

\section{Samenvatting en conclusies}

In dit werk is getracht een empirisch onderzoek te doen naar de invloed van beschermingsconstructies op aandelenkoersen. Uit de theorie zijn twee verschillende hypothesen over de invloed van beschermingsconstructies op aandelenkoersen naar voren gekomen die geheel tegengesteld zijn. De eerste is de 'managerial entrenchment'-hypothese die zegt dat er een negatieve werking uitgaat van de invoering van beschermingsconstructies op aandelenkoersen, terwijl de 'stockholder interests'-hypothese uitgaat van een positieve werking.

Het onderzoek spitst zich toe op een analyse van preferente beschermingsaandelen bij beursgenoteerde ondernemingen. Op basis van de totale steekproef van alle beschermingsmaatregelen met preferente aandelen is het resultaat dat er een significant negatief effect is van de invoering van de bescherming op de aandelenkoersen. Hierdoor wordt de 'managerial entrenchment'-hypothese niet verworpen. Als de totale steekproef van beschermingsmaatregelen wordt verdeeld in de drie stappen van het beschermingsproces, dan blijken de resultaten van de totale steekproef te worden bepaald door de laatste stap, de uitgifte van preferente be- 
schermingsaandelen. De bekendmaking veroorzaakt een sterke koers daling ten gevolge van de beschermingsmaatregel. Deze daling wordt nog eens bevestigd als wordt gekeken naar het gemiddelde gecumuleerde buitengewone rendement vanaf de bekendmaking tot aan het eind van de 'event'periode. Dan blijkt er een rendementsverlies te zijn van bijna $10 \%$. Hierdoor wordt de 'managerial entrenchment'-hypothese bevestigd voor wat de uitgifte van preferente beschermingsaandelen betreft.

Tenslotte is geanalyseerd of het uitmaakt of de onderneming voor het eerst preferente beschermingsaandelen heeft uitgegeven, dan wel dat er sprake is van een extra plaatsing. Als er sprake is van een eerste plaatsing dan blijkt dat het effect sterker is. Een extra plaatsing treft de aandeelhouders minder zwaar dan de eerste plaatsing.

Op grond van deze resultaten kan worden gezegd dat van de bescherming met preferente aandelen een drukkende werking uitgaat op de aandelenkoers. Dit geldt in sterke mate voor de bekendmaking van de uitgifte van preferente beschermingsaandelen. In de discussie over de wenselijkheid van beschermingsconstructies wordt het argument, dat de invoering van bescherming de aandelenkoers drukt, op grond van deze resultaten bevestigd.

\section{Literatuur}

Barkema, H.G., De welvaartseffecten van de fusie Nationale Nederlanden - NMB Postbank Groep. Economische Statistische Berichten, 1992, pp. 201-204.

Blanco Fernandez, J.M.. Uitgifte van beschermingsaandelen, Naamlooze Vennootschap. deel 67, 1989. pp. 153-158.

Brown. S.J. en J.B. Warner, Measuring security price performance, Journal of Financial Economics, vol 8, 1980. pp. 205-258.

Brown, S.J. en J.B. Warner, Using daily stock returns, the case of event studies, Journal of Financial Economics, vol 14, 1985, pp. 3-31.

Cremers, R.H.M.A. en A.Tourani Rad, De fusie tussen Nationale Nederlanden en NMB-Postbank Groep: een empirisch onderzoek naar de welvaart van de aandeelhouders. Maandblad Accountancy en Bedriffseconomie. Jrg. 66. 1992, pp. 147-152.

Dann, L.Y. en H. DeAngelo, Standstill agreements. privately negotiated stock repurchases, and the market for corporate control. Journal of Financial Economics, vol 11, 1983, pp 275-300.

DeAngelo, H. en E.M. Rice. Antitakeover charter amendments and stockholder wealth. Journal of Financial Economics, vol 11, 1983, pp. 329-360

Fama. E.F., Efficient capital markets: II. Journal of Finance, vol
46. 1991. pp. 1575-1617.

Frentrop. P., Beschermingsconstructies - een verhitte discussie. Economische Statistische Berichten, 1988. pp. 836-841.

Jong, H.W. de, De overnemingsmarkt in Europa, Maandblad voor Accountancy en Bedrijfseconomie, Jrg. 64, 1990. pp. 595-614

Kabir. R.. Share price and trading volume behaviour around trading suspensions, Maandblad voor Accountancy en Bedrijfseconomie, Jrg. 66. 1992, pp. 49-56.

Moerland. P.W., De Overnemingsmarkt: Theorie, empirie en regelgeving, Maandblad voor Accountancy en Bedrijfseconomie. Jrg. 63, 1989, pp. 143-161.

Rietkerk, G.. Beschermingsconstructies en managementverschansing, in Dorsman. A.B. e.a., red., Het financieel systeem in ontwikkeling. Stenfert Kroese. 1989, pp. 57-68.

Schwarz. C.A., Certificering van aandelen, vitgifte van beschermingsprefs en de rol van de stichting, Stichting \& Vereniging 1988. pp. 103-107.

Voogd, R.P.. Statutaire beschermingsmiddelen bij beursvennootschappen, proefschrift Universiteit Nijmegen. Kluwer, 1989.

Voogd. R.P., Congresbundel Beschermingsconstructies, Kluwer. 1990a. pp. 107-120.

Voogd, R.P., Beschermingsconstructies, mede in Europees perspectief, Maandblad voor Accountancy en Bedrifseconomie, jrg. 64, 1990b. pp. 568-580.

\section{Noten}

1 De auteurs zijn Drs. P. Duffhues, Drs. H. Oosterhout, Prof. Dr. $P$. Moerland, en de redactieraad-financiering van MAB erkentelijk voor hun commentaar.

2 Zie bijvoorbeeld Het Financieele Dagblad, 31 oktober 1991, 19 november 1991, 14 en 15 januari 1992.

3 Het Financieele Dagblad, overzicht van 35 hoofdfondsen en 120 lokale fondsen, 5 juli 1988.

$4 \mathrm{Er}$ is uiteraard alleen gekeken naar het belang van de aandeelhouders. Belangen van andere 'stakeholders', zoals werknemers en leveranciers, zijn hier niet getoetst.

5 Voor het onderzoek is de periode 1984-1990 genomen. 6 Opvallend is dat er in 1990 geen enkele beschermingsmaatregel is gevonden. Een mogelijke verklaring hiervoor is dat per 1 november 1989 de Vereniging voor de Effectenhandel maatregelen heeft getroffen die het invoeren van beschermingsconstructies moeilijker maken zodat ondernemingen in de periode ervoor hun beschermingsconstructies hebben aangescherpt. Dit blijkt tevens uit het feit dat in 1989 relatief meer beschermingsmaatregelen zijn getroffen.

$7 \mathrm{Er}$ zijn in deze steekproef slechts 9 gevallen opgenomen waar op de dag van bekendmaking van de beschermingsmaatregel ook andere koersgevoelige informatie heeft kunnen vrij komen: het betreft 4 aandelensplitsingen en 5 bekendmakingen van de (half)jaarcijfers.

8 Huidige en potentiële aandeelhouders, alsmede insiders en de Beurs zijn dan al op de hoogte van de nieuw vrijgekomen informatie en wordt dan volgens de efficiënte markthypothese in de beurskoers verwerkt.

9 Fama (1991) acht het nut van 'event'-studies groot, vooral het effect van informatie de eerste dagen dat de beurs kan reageren. Deze methodiek is in Nederland recent nog toegepast in de onderzoeken van Barkema (1992), Cremers en Tourani Rad (1992) 
en Kabir (1992).

10 Het betreft de optieverlening van Volker Stevin (30 jan '89), de optieverlening van Grolsch (9 nov '89) en de tweede uitgifte van Volker Stevin (20 dec '88).

11 Het betreft 12 dagen van de optieverlening van Reesink (15 maart ' 89 ), 8 dagen van de uitgifte van Desseaux (13 juni ' 85 ) en 9 dagen van de uitgifte van Ahold (28 aug '89).

12 Deze resultaten zijn gegeven volgens het Markt Model. De resultaten op basis van het 'Market Adjusted Returns'-model worden niet vermeld omdat ze geen essentiële verschillen vertonen met het Markt Model.

13 De extra uitgifte van Volker Stevin (20 dec ' 88 ) is niet in de steekproef meegenomen omdat de schattingsperiode samenviel met de 'event'-periode van een eerdere uitgifte (3 okt ' 88 ).

14 De desbetreffende ondernemingen staan vermeld in tabel 1. 